\title{
Prediction of soil and water conservation structure impacts on runoff and erosion processes using SWAT model in the northern Ethiopian highlands
}

\author{
Nigus Demelash Melaku ${ }^{1,2,3}$ (D) Chris S. Renschler ${ }^{1,2} \cdot$ Hubert Holzmann $^{1} \cdot$ Stefan Strohmeier ${ }^{4} \cdot$ Wondimu Bayu $^{5}$. \\ Claudio Zucca ${ }^{4}$ - Feras Ziadat ${ }^{6}$ - Andreas Klik ${ }^{1}$
}

Received: 12 August 2017 / Accepted: 13 December 2017 / Published online: 23 December 2017

(C) The Author(s) 2017. This article is an open access publication

\begin{abstract}
Purpose Land degradation due to soil erosion is a serious threat to the highlands of Ethiopia. Various soil and water conservation (SWC) strategies have been in use to tackle soil erosion. However, the effectiveness of SWC measures on runoff dynamics and sediment load in terms of their medium- and short-term effects has not been sufficiently studied. Materials and methods A study was conducted in 2011 to 2015 in the Gumara-Maksegnit watershed to study the impacts of SWC structures on runoff and soil erosion processes using the soil and water analysis tool (SWAT) model. The study was conducted in two adjacent watersheds where in one of the watersheds, SWC structures were constructed (treated watershed (TW)) in 2011, while the other watershed was a reference watershed without SWC structures (untreated watershed (UW)). For both watersheds, separate SWAT and SWAT-CUP (SWAT calibration and uncertainty procedure) projects were set up for daily runoff and sediment yield. The SWAT-CUP program was applied to optimize the parameters of the SWAT using daily observed runoff and sediment yield data.

Results and discussion The runoff simulations indicated that SWAT can reproduce the hydrological regime for both watersheds. The daily runoff calibration (2011-2013) results for the TW and UW showed good correlation between the predicted and the observed data $\left(R^{2}=0.78\right.$ for the TW and $R^{2}=0.77$ for the UW). The validation (2014-2015) results also showed good correlation with $R^{2}$ values of 0.72 and 0.70 for the TW and UW, respectively. However, sediment yield calibration and validation results showed modest correlation between the predicted and observed sediment yields with $R^{2}$ values of 0.65 and 0.69 for the TW and UW for the calibration and $R^{2}$ values of 0.55 and 0.65 for the TW and UW for the validation, respectively.

Conclusions The model results indicated that SWC structures considerably reduced soil loss by as much as $25-38 \%$ in the TW. The study demonstrated that SWAT performed well for both watersheds and can be a potential instrument for upscaling and assessing the impact of SWC structures on sediment loads in the highlands of Ethiopia.
\end{abstract}

Keywords Runoff $\cdot$ Sediment yield $\cdot$ SWAT $\cdot$ SWAT-CUP $\cdot$ SWC $\cdot$ Watershed

Responsible editor: Hugh Smith

Nigus Demelash Melaku nigus.melaku@students.boku.ac.at

University of Natural Resources and Life Sciences, Vienna, Austria

2 LESAM, University at Buffalo, The State University of New York, New York, NY, USA
Gondar Agricultural Research Center, Gondar, Ethiopia

4 International Center for Agricultural Research in the Dry Areas, Amman, Jordan

5 Catholic Relief Services, Addis Ababa, Ethiopia

6 Food and Agriculture Organization of the United Nations, Rome, Italy 


\section{Introduction}

The degradation of agricultural land as a result of soil erosion is a worldwide phenomenon leading to the loss of nutrientrich surface soil and increased runoff from the more impermeable sub-soil that leads to the lowering of agricultural productivity (Erkossa et al. 2015; Taguas et al. 2015; Ganasri and Ramesh 2015; Keesstra et al. 2016; Nigussie et al. 2017). Soil erosion is more severe in the sub-Saharan African countries where the population livelihood is dependent on the soil (Sunday et al. 2012; Erkossa et al. 2015). In the Ethiopian highlands, deforestation for crop production, cultivation of marginal lands, and overgrazing are the major factors that dramatically increased the vulnerability of agricultural lands to rainfall-driven soil erosion (Nyssen et al. 2000; Vancampenhout et al. 2006; Belay et al. 2014; Adimassu et al. 2014; Erkossa et al. 2015; Addis et al. 2016). Intensive rainfall during rainy seasons (June to September) contributes to severe land degradation in mountainous regions, especially on steep sloping and unprotected areas (Addis et al. 2016).To tackle the soil erosion problem in the Ethiopian highlands, constructing soil and water conservation structures is considered to be a top priority in halting land degradation and thus to improve agricultural productivity.

Since 2010, a massive effort has been undertaken by the government of Ethiopia in constructing soil and water conservation structures on privately owned and community lands through community mobilization (Kebede 2014; Dagnew et al. 2015; Teshome et al. 2016; Dagnew et al. 2017; Grum et al. 2017; Guzman et al. 2017). Examples of soil and water conservation practices include stone bunds, soil bunds, and percolation ditches (Teshome et al. 2016). However, the effectiveness of these soil and water conservation measures on the dynamics of watershed-scale runoff and sediment loading has not been sufficiently studied and identified clearly for long- and short-term effects in the Ethiopian highlands.

In the northern highlands of Ethiopia, different studies have been carried out on the impacts of soil and water conservation structures on erosion process at the field scale (Kaltenleithneret al. 2014; Rieder et al. 2014; Strohmeier et al. 2015; Klik et al. 2016; Obereder et al. 2016). These studies reported that the soil and water conservation (SWC) structures are effective at the plot scale in the GumaraMaksegnit watersheds. However, studies on the impacts of soil and water structures on erosion process at the watershed scale are limited. As data from field experiments cannot be extrapolated to a watershed scale (Verstraeten et al. 2006), the use of mathematical models for evaluating soil and water conservation measures is quite common.

Insufficient information on soil erosion and streamflow could lead to inefficient planning and inadequate design and operation of soil and water resource management projects
(Poitras et al. 2011). Changes in the extent of seasonal precipitation, frequency, and intensity of extreme precipitation events directly affect the amount of seasonal streamflow (Poitras et al. 2011). The prediction and assessment of streamflow and sediment yield using a watershed model are important for agricultural watershed management in the Ethiopian highlands as watershed models are crucial tools to illustrate hydrological processes and to scale up the model results.

The soil and water assessment tool (SWAT; Arnold et al. 1998) is a continuous-time, semi-distributed, process-based river basin- or watershed-scale model. The model is one of the most comprehensive models able to evaluate hydrologic processes (Gassman et al. 2007). SWAT has been employed to simulate the discharge in the Ethiopian highlands (Setegn et al. 2008; Setegn et al. 2009; Easton et al. 2010; Setegn et al. 2010; Betrie et al. 2011; Setegn et al. 2011). Hence, the objectives of this study were (1) to calibrate and validate the SWAT model for two watersheds with and without SWC structures, (2) to study the impact of these structures on runoff and erosion processes, and (3) to provide feedback on the efficiency of the structures in reducing soil erosion in the watersheds and to advise future upscaling.

\section{Materials and methods}

\subsection{Description of the study area}

The two study watersheds, treated watershed (TW) and untreated watershed (UW), are located in the GumaraMaksegnit watershed in northwest Ethiopia (Fig. 1). The watersheds drain into the Gumara River which finally drains into Lake Tana. They are located at $12^{\circ} 25^{\prime} 24^{\prime \prime}$ and $12^{\circ} 25^{\prime} 54^{\prime \prime}$ latitude and at $37^{\circ} 34^{\prime} 56^{\prime \prime}$ and $37^{\circ} 35^{\prime}$ $38^{\prime \prime}$ longitude and at an altitude ranging from 1998 to $2150 \mathrm{~m}$ above sea level (Fig. 1). The two study watersheds are neighboring each other at a distance of $1 \mathrm{~km}$ between the outlets. The TW has an area of 27.1 ha, and the UW has an area of 31.7 ha. The slope of the watershed ranges from 2 to $69 \%$ with an average slope of $14.8 \%$. The soil types in the watersheds are Cambisol and Leptosol which are found in the upper and central parts of the watershed, while Vertisols are found in the lower catchment. The watershed is characterized as subhumid. It has a long term (1997-2015) mean annual rainfall of $1157 \mathrm{~mm}$ with $80 \%$ raining from June to September and mean minimum and maximum temperatures of 13.3 and $28.5{ }^{\circ} \mathrm{C}$, respectively (Addis et al. 2016).

In 2011, stone and soil bunds were constructed as SWC structures in TW. Stone and soil bunds are SWC structures made of stones or soil constructed along a contour in order to 


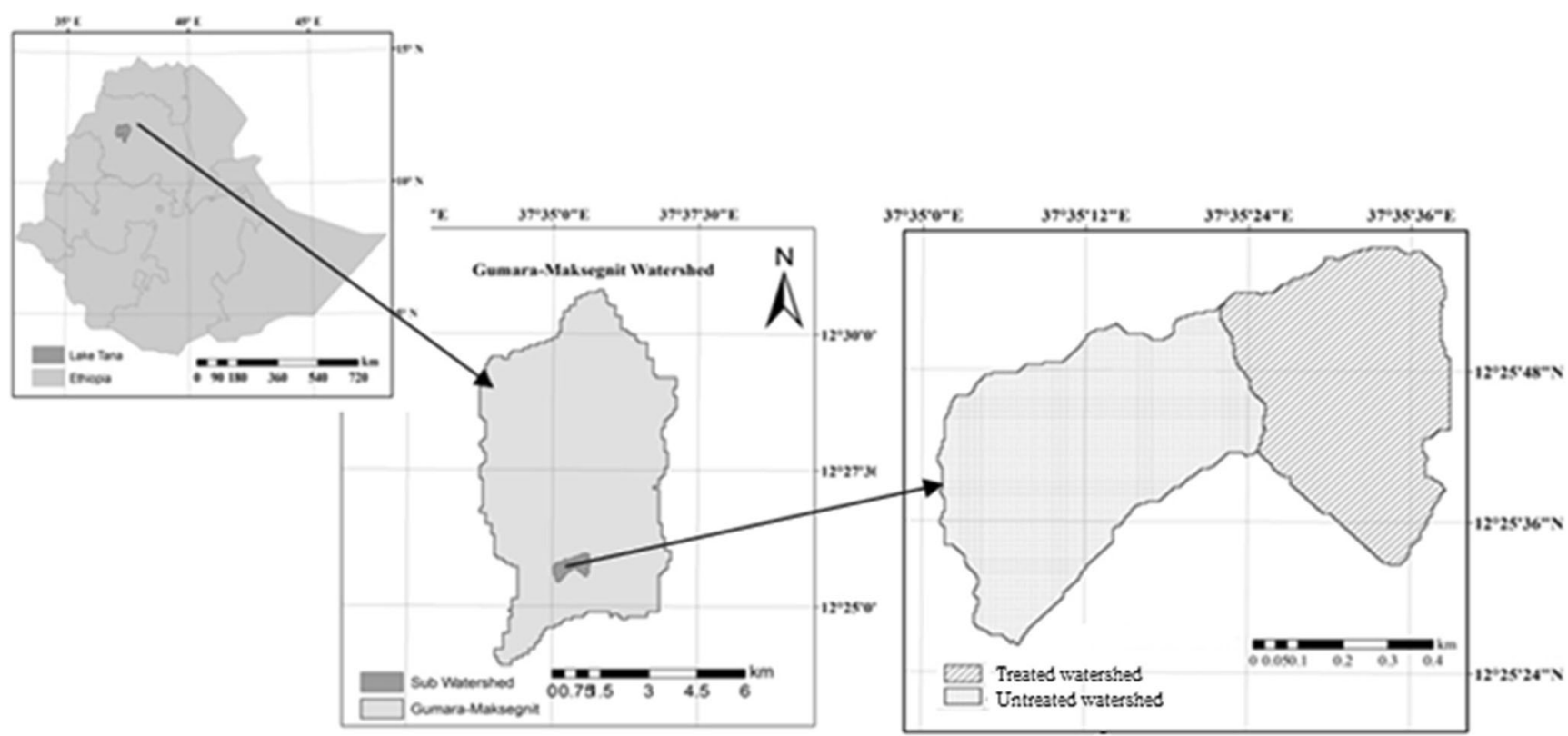

Fig. 1 Maps of Ethiopia (left top), the larger Gumara-Maksegnit watershed (middle), and the two paired watersheds (right)

best slow the water flowing down the slope, which prevents soil erosion (Fig. 2). On farmlands, 40-cm-high stone and soil bunds at distances ranging between 15 and $25 \mathrm{~m}$ depending on the steepness of the land were constructed along the contour. Gullies were treated with check dams. The UW was used as a reference without any SWC structures. Similar dominance of land use, soil texture/type, and topography of these two watersheds were used as basis for the comparison between TW and UW (Fig. 3). The main staple food crops in the watershed are sorghum, teff, barley, beans, wheat, and corn. The main crop rotations are chickpea followed by teff followed by sorghum (chickpea-teff-sorghum), chickpea followed by wheat followed by sorghum (chickpea-wheat-sorghum), and beans followed by barley followed by corn (beans-barley-corn).

\subsection{Runoff discharge and sediment yield}

Runoff and sediment yield were determined at the outlet of both watersheds where rectangular v-notch weirs with flow sensors and automatic cameras were installed. Gauges were marked on the walls of the weirs, and the cameras took pictures every 2 min (Fig. 4). Discharges were then calculated using a rating curve developed on measurements by Zehetbauer et al. (2013). During each rainfall event, runoff samples were collected at three times during the runoff event. Samplings were made approximately at the start of runoff, the middle of the runoff event, and towards the end of the event. Samples were taken in triplicate with a volume of approximately $3 \mathrm{~L}$ each. For each event, an average sediment concentration in each sample was determined in the soil laboratory. Sediment yield was then obtained by multiplying runoff discharge by the sediment concentration. The data from 2011 to 2013 were used to calibrate and those from 2014 to 2015 were used to verify the distributed SWAT model.

\subsection{SWAT model and model input}

The SWAT was used to estimate runoff and sediment yield in the TW and UW watersheds. Surface runoff was modified by the adjustment of the runoff ratio (curve number) (Bonta
Fig. 2 Erosion plot experiments (left) and SWC structures (right) at the treated watershed
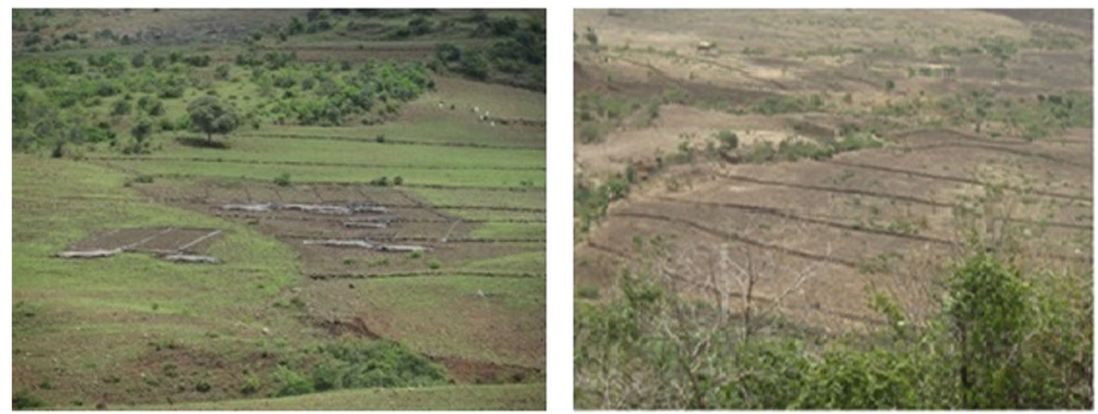
1997a, b) while SWC structures' impact on sediment yield was adjusted through the support practice factor (P-factor) and/or the slope length factor (LS).

Curve number values were modified by editing the management (.mgt) input table from the field experiment data results (Klik et al. 2016) while the average slope length (SLSSUBSN) value was modified by editing the hydrologic response unit (HRU) (.hru) input table. The watershed was divided into a number of sub-basins with different HRUs. The HRU represents the unique property of each parameter in the watershed. Parameters like surface runoff, sediment yield, soil moisture, nutrient dynamics, and crop growth were simulated for each HRU, aggregated, and processed to sub-basin level on a daily time step resolution. Input data are required for SWAT model that can be supplemented with GIS data and the model interface (Di Luzio et al. 2002).

For this study, SWAT offers finer spatial and temporal scales, which allow observation of output at a particular subbasin on a daily basis. Digital elevation model (DEM), land
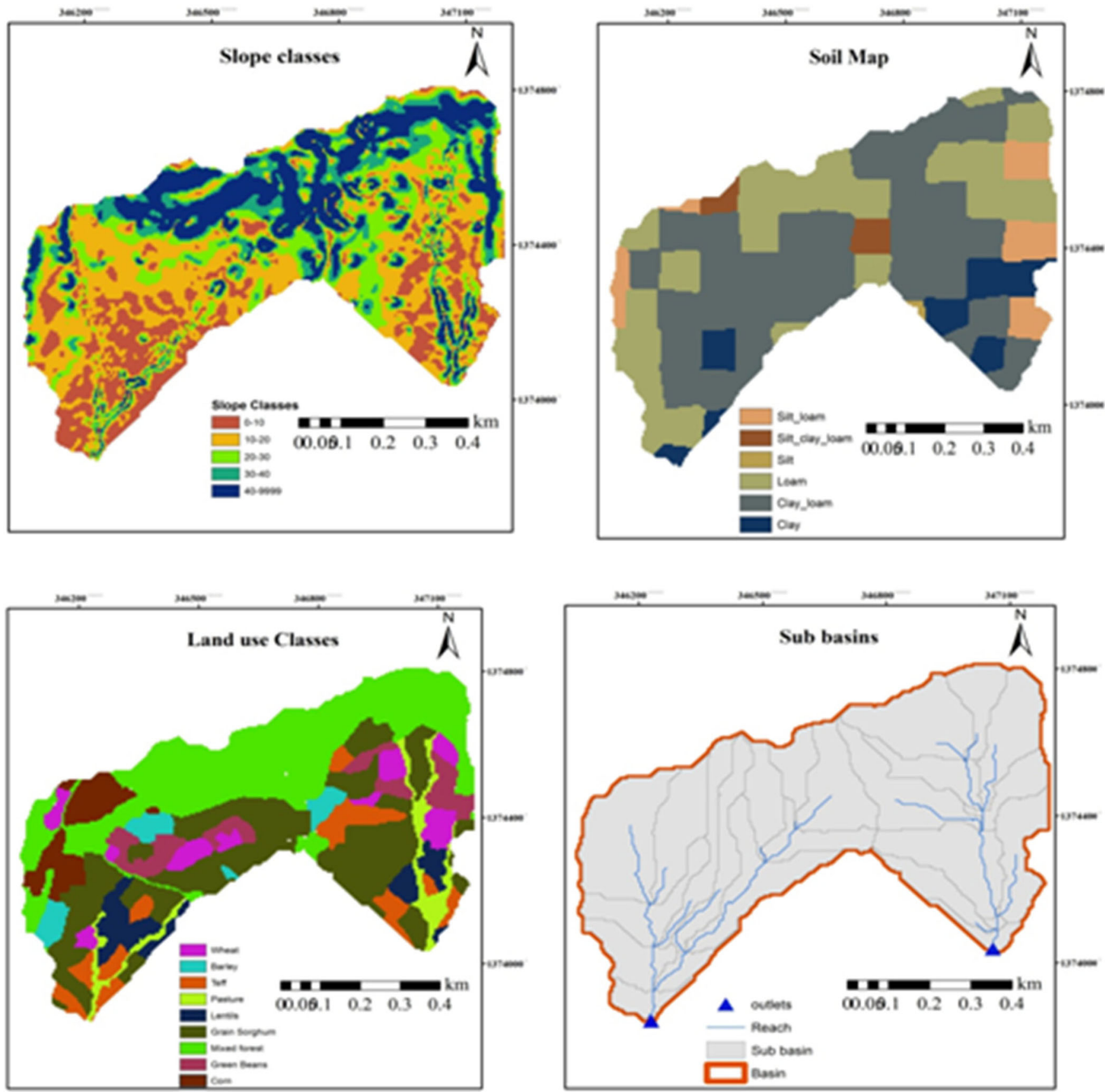

Fig. 3 Slope classes, soil map, land use classes, and sub-basins of both watersheds 
Fig. 4 Pictures taken from the automatic camera at day (left) and nighttime (right)
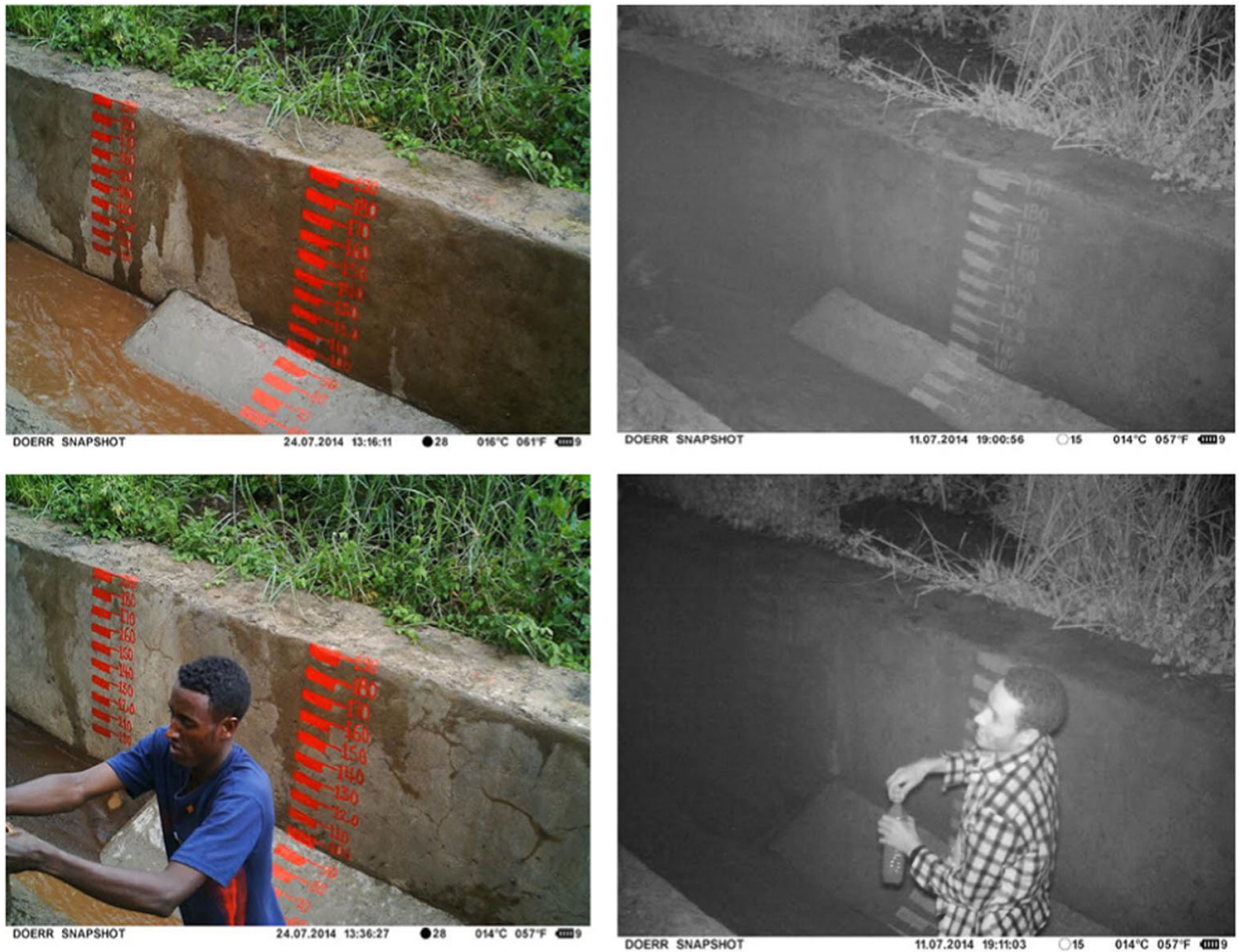

use, and soil and climate data were used as inputs for the SWAT model.

\subsection{Model input}

A DEM of the watershed was developed with 5-m resolution at 2556 coordinate points using a total station to derive topographical parameters and automatically delineate watershed boundaries and channel networks. The study watersheds were divided

Table 1 Land use and land cover in the untreated and treated watersheds

\begin{tabular}{lll}
\hline Land use type & $\begin{array}{l}\text { Untreated watershed (UW) } \\
(\%)\end{array}$ & $\begin{array}{l}\text { Treated watershed (TW) } \\
(\%)\end{array}$ \\
\hline Barley & 4.7 & 2.3 \\
Lentils & 6.2 & 4.6 \\
Green beans & 5.9 & 7.4 \\
Pasture & 2.4 & 6.9 \\
Corn & 10.1 & 5.1 \\
Mixed forest & 33.2 & 30.4 \\
Grain & 28.4 & 27.3 \\
$\quad$ sorghum & & \\
Eragrostis & 4.1 & 9.1 \\
$\quad$ teff & & 6.9 \\
Wheat & 5.0 & 100 \\
Total & 100 & \\
\hline
\end{tabular}

into the following five slope steepness classes: 0-10, 10-20, 20 30, 30-40, and greater than 40\% (Fig. 3). Nine land use classes were developed for the study watersheds (Fig. 3) using Google Earth imagery taken on 14 October 2011 which were crosschecked using ground truth data. The land use percentages of each watershed are summarized in Table 1.

Soil physical and chemical properties of both watersheds were determined from soil samples collected from a $100 \mathrm{~m}$ by $100 \mathrm{~m}$ grids at 0-25-, 25-60-, and 60-100-cm soil depths. The UW has soil textural classes comprised of $3.7 \%$ clay, $52.9 \%$ clay loam, $36.3 \%$ loam, $4.7 \%$ silty clay loam, and $2.9 \%$ silty loam. Similarly, the TW has textural classes of $12.4 \%$ clay, $50.7 \%$ clay loam, $23.4 \%$ loam, $0.16 \%$ silty clay loam, and $12.9 \%$ silty loam (Fig. 3).

Daily precipitation and temperature data were collected from a weather station located at the outlets of UW. Daily solar radiation, relative humidity, and wind speed data were recorded from an automatic weather station installed approximately at a distance of $5 \mathrm{~km}$ from the watersheds. Missing daily weather data were simulated using SWAT weather generator (Schuol and Abbaspour 2007). Daily weather data (January 1, 1997 to December 31, 2015) recorded at both weather stations were used to create the weather statistics using the weather generator.

\subsection{Project setup}

For each watershed, a separate SWAT project was set up. The modeled period was from 2004 to 2015. Runoff and 
Table 2 List of parameters adjusted for runoff during the calibration process

\begin{tabular}{|c|c|c|c|c|c|}
\hline \multirow[t]{2}{*}{ Parameter name } & \multirow[t]{2}{*}{ Description } & \multicolumn{2}{|c|}{ Fitted value } & \multirow[t]{2}{*}{ Range } & \multirow[t]{2}{*}{ Rank } \\
\hline & & UW & TW & & \\
\hline $\mathrm{R} \_\mathrm{CN} 2 . \mathrm{mgt}$ & Curve number & -0.013 & 0.065 & $-0.25-0.25$ & 1 \\
\hline V_RCHRG_DP.gw & Deep aquifer percolation fraction & 0.19 & 0.1 & $0-0.2$ & 2 \\
\hline V__SURLAG.bsn & Surface runoff lag coefficient & 9.33 & 5.5 & $1-10$ & 3 \\
\hline V_GW_DELAY.gw & Groundwater delay time (days) & 262.5 & 250 & $0-500$ & 4 \\
\hline $\mathrm{R} \_$SOL_K (1).sol & Saturated hydraulic conductivity & -0.16 & -0.17 & $-0.25-0.25$ & 5 \\
\hline V_REVAPMN.gw & $\begin{array}{l}\text { Threshold depth of water in the shallow } \\
\text { aquifer percolation to the deep aquifer } \\
\text { to occur }\left(\mathrm{mm} \mathrm{H}_{2} \mathrm{O}\right)\end{array}$ & 337 & 250 & $0-500$ & 6 \\
\hline V_GW_REVAP.gw & Groundwater "revap" coefficient & 0.09 & 0.17 & $0-0.2$ & 7 \\
\hline $\mathrm{V} \_$CH_N2.rte & Manning's $n$ value for the main channel & 0.26 & 0.15 & $0-0.3$ & 8 \\
\hline V_ALPHA_BF.gw & Base flow alpha factor (days) & 0.23 & 0.5 & $0-1$ & 9 \\
\hline V_GWQMN.gw & $\begin{array}{l}\text { Threshold depth of water in the shallow } \\
\text { aquifer required for return flow to occur } \\
\left(\mathrm{mm} \mathrm{H}_{2} \mathrm{O}\right)\end{array}$ & 875 & 833.3 & $0-5000$ & 10 \\
\hline R_SOL_AWC (1).sol & Soil available water storage capacity & -0.11 & -0.17 & $-0.25-0.25$ & 11 \\
\hline V_ESCO.hru & Plant uptake compensation factor & 0.48 & 0.84 & $0.01-1$ & 12 \\
\hline
\end{tabular}

$U W$ untreated watershed, $T W$ treated watershed

sediment yield data collected from the watersheds during 2011 to 2013 were used for model calibration while data from 2014 to 2015 were used for validation. Mean daily runoff and sediment data from both watersheds were used to calibrate the SWAT model. Some of the appropriate parameters were adjusted until the predicted daily runoff (Table 2) and sediment yield (Table 3) approximately matched the measured ones at the outlets of the watershed. Based on the given threshold areas and manual input data, automatic sub-basin delineation was done for the UW and TW (Fig. 3d). The SWAT model divided the sub- basin into detailed HRUs. The model delineates each HRUs with a user-defined threshold based on the percentage of the slope classes, soil type, and land use (Arnold et al. 2011).

The HRUs for this study were delineated using the soil type and the land use thresholds set at 5\% area coverage. Any soil type and land use type each covering more than $5 \%$ of the subbasin area were considered as an HRU. Based on the thresholds selected, there were a total of 760 HRUs in the UW and 658 HRUs in the TW. These HRUs were used for analyses on a particular land use, soil type, and slope class.

Table 3 List of parameters adjusted for sediment during the calibration process

\begin{tabular}{|c|c|c|c|c|c|}
\hline \multirow[t]{2}{*}{ Parameter name } & \multirow[t]{2}{*}{ Description } & \multicolumn{2}{|c|}{ Fitted value } & \multirow[t]{2}{*}{ Range } & \multirow[t]{2}{*}{ Rank } \\
\hline & & UW & TW & & \\
\hline R_USLE_K.sol & USLE soil erodibility factor & 0.17 & 0.19 & $0.15-0.35$ & 1 \\
\hline V__USLE_P.mgt & USLE support practice factor & 0.79 & 0.72 & $-0.01-0.8$ & 2 \\
\hline $\mathrm{V}_{ـ}$ SPEXP.bsn & $\begin{array}{l}\text { Exponent parameter for calculating } \\
\text { sediment in channel routing. }\end{array}$ & 1.2 & 1.06 & $1-1.4$ & 3 \\
\hline V_SPCON.bsn & $\begin{array}{l}\text { Linear parameter for calculating the } \\
\text { maximum amount of sediment that } \\
\text { can be re-entrained during channel } \\
\text { sediment routing }\end{array}$ & 0.02 & 0.04 & $0-0.05$ & 4 \\
\hline R_CH_K2.rte & $\begin{array}{l}\text { Effective hydraulic conductivity in } \\
\text { main channel alluvium }\end{array}$ & -0.08 & -0.11 & $-0.2-0.2$ & 5 \\
\hline V_CH_N2.rte & Manning's $n$ value for the main channel & 0.24 & 0.21 & $0-0.3$ & 6 \\
\hline V_CH_COV1.rte & Channel erodibility factor & 0.29 & 0.36 & $0.0-0.5$ & 7 \\
\hline V_CH_COV2.rte & Channel cover factor & 0.50 & 0.55 & $0.001-1$ & 8 \\
\hline
\end{tabular}




\subsection{Model performance evaluation}

Graphical and statistical model evaluation techniques were used to see how well the simulated results match the observed data. SWAT and SWAT-CUP calibration tools provide multiple model evaluation statistical criteria to be selected as an objective function for model calibration and validation based on the recommendations suggested by Santhi et al. (2001) and Moriasi et al. (2007). The SUFI-2 (Sequential Uncertainty Fitting 2) program which is linked to SWAT-CUP2012 version 5.1.6.3 was used for a combined model sensitivity analysis, calibration, and validation procedures (Abbaspour et al. 2004, 2007). The SUFI-2 algorithm accounts for different sources of parameter uncertainty, conceptual model uncertainty, and input data uncertainty (Gupta et al. 2006). In this study, coefficient of determination $\left(R^{2}\right)$ (Krause et al. 2005), Nash-Sutcliffe efficiency (NSE) (Nash and Sutcliffe 1970), and percent bias (PBIAS) (Gupta et al. 1999) evaluation statistics were used to see the goodness of fit of the model (Santhi et al. 2001; Moriasi et al. 2007). The equations used are

$R^{2}=\left[\frac{\sum_{i=1}^{n}\left(O_{i}-\bar{O}\right)\left(E_{i}-\bar{E}\right)}{\sqrt{\sum_{i=1}^{n}\left(O_{i}-\bar{O}\right)^{2}} \sqrt{\sum_{i=1}^{n}\left(E_{i}-\bar{E}\right)^{2}}}\right]^{2}$

where $n$ is the number of observations or samples, $O_{i}$ is the observed values, $E_{i}$ is the estimated values, $\bar{O}$ is the mean of observed values, $\bar{E}$ is the mean of estimated values, and $I$ is the counter for individual observed and predicted values. The $R^{2}$ ranges between 0 and 1, where 1 means that the predicted value is equal to the observed value and zero means that there is no correlation between the predicted and observed values.

$\mathrm{NSE}=1-\frac{\sum_{i=1}^{n}\left(E_{i}-O_{i}\right)^{2}}{\sum_{i=1}^{n}\left(O_{i}-\bar{O}\right)^{2}}$

The range of $E$ lies between $-\infty$ and 1.0 with $E=1$ describing a perfect fit. Values between 0 and 1.0 are generally viewed as acceptable levels of performance, whereas values $<0$ indicate that the mean observed value is a better predictor than the model.

PBIAS $=\left[\frac{\sum_{i=1}^{n}\left(O_{i}-E_{i}\right) \times 100}{\sum_{i=1}^{n}\left(O_{i}\right)}\right]$

The optimal value of PBIAS is 0 , with low-magnitude values indicating accurate model simulation (Moriasi et al. 2007).

\section{Results}

\subsection{Runoff calibration and validation}

Results showed that the observed mean daily discharge was $0.03 \mathrm{~m}^{3} \mathrm{~s}^{-1}$ for the calibration period and $0.02 \mathrm{~m}^{3} \mathrm{~s}^{-1}$ for the validation period whereas the estimated mean daily discharge was $0.03 \mathrm{~m}^{3} \mathrm{~s}^{-1}$ for the calibration period and validation period in the UW (Table 4). The simulation results showed that the $R^{2}$ and NSE values for the daily runoff in the UW were 0.77 and 0.75 for the calibration period and 0.72 and 0.56 for the validation period, respectively (Table 4). PBIAS was -8.9 for the calibration and 14.8 for validation for the UW.

Similarly, the estimated and the observed daily discharge for the TW was $0.02 \mathrm{~m}^{3} \mathrm{~s}^{-1}$ for the calibration and validation periods (Table 4 ). The daily runoff simulation results showed better model efficiency with a $R^{2}$ value for the daily runoff of 0.78 for the calibration period and 0.70 for the validation period (Table 4). The NSE values were 0.63 for calibration and 0.58 for validation periods (Table 4). The mean daily results give PBIAS of 29.2 for calibration and 24.3 for the validation periods (Table 4) indicating that the model performed well according to Moriasi et al. (2007). Results showed that there is good agreement between the observed and predicted daily runoff for both TW and UW during calibration and validation periods (Figs. 5 and 6) indicating that SWAT performs well. This indicates that the model predicts the daily discharge very well (Figs. 5 and 6).

The observed runoff on the same day was often under predicted for the calibration period and for the validation period. Based on the model results, the mean daily runoff from both watersheds shows better agreement with the measured runoff calibration and validation periods (Fig. $7 \mathrm{a}, \mathrm{b}$ ). The evaluation coefficients of the simulated daily runoff of different objective functions for both the TW and UW indicated satisfactory model fit according to the assessment criteria (Moriasi et al. 2007). Khelifa et al. (2016) reported daily runoff with NSE values of 0.64 for calibration and 0.68 for validation. Similar studies are in better agreement with these results (Addis et al. 2016; Zimale et al. 2016). For a study in the Gumara watershed by Zimale et al. (2016), the NSE values for daily flows obtained were 0.70 for calibration and 0.77 for validation period.

\subsection{Sediment calibration and validation}

Daily sediment yield was calibrated and validated using the measured data from the two watersheds. Sediment yield prediction results gave a $R^{2}$ of 0.69 for calibration and 0.65 for 
Table 4 Mean daily discharge, sediment yield and summary statistics of treated and untreated watersheds

\begin{tabular}{|c|c|c|c|c|}
\hline \multirow[t]{2}{*}{ Parameter } & \multicolumn{2}{|l|}{ Calibration } & \multicolumn{2}{|l|}{ Validation } \\
\hline & $\begin{array}{l}\text { Observed } \\
\text { (standard } \\
\text { deviation) }\end{array}$ & $\begin{array}{l}\text { Simulated } \\
\text { (standard } \\
\text { deviation) }\end{array}$ & $\begin{array}{l}\text { Observed } \\
\text { (standard } \\
\text { deviation) }\end{array}$ & $\begin{array}{l}\text { Simulated } \\
\text { (standard } \\
\text { deviation) }\end{array}$ \\
\hline
\end{tabular}

\begin{tabular}{|c|c|c|c|c|}
\hline \multicolumn{5}{|c|}{ Untreated watershed } \\
\hline $\begin{array}{l}\text { Mean daily } \\
\text { discharge } \\
\left(\mathrm{m}^{3} \mathrm{~s}^{-1}\right)\end{array}$ & $0.03(0.02)$ & $0.03(0.02)$ & $0.03(0.02)$ & $0.02(0.02)$ \\
\hline $\begin{array}{l}\text { Mean daily } \\
\text { sediment } \\
\text { yield } \\
\left(\mathrm{t} \mathrm{ha}^{-1}\right)\end{array}$ & $4.19(4.05)$ & $2.86(4.22)$ & $3.71(2.46)$ & $2.63(2.89)$ \\
\hline \multicolumn{5}{|l|}{ Discharge } \\
\hline $\mathrm{R} 2$ & 0.77 & & 0.72 & \\
\hline NSE & 0.75 & & 0.56 & \\
\hline PBIAS & -8.9 & & 14.2 & \\
\hline \multicolumn{5}{|c|}{ Sediment yield } \\
\hline $\mathrm{R} 2$ & 0.69 & & 0.65 & \\
\hline NSE & 0.54 & & 0.33 & \\
\hline PBIAS & 29.2 & & 24.3 & \\
\hline \multicolumn{5}{|c|}{ Treated watershed } \\
\hline $\begin{array}{l}\text { Mean daily } \\
\text { discharge } \\
\left(\mathrm{m}^{3} \mathrm{~s}^{-1}\right)\end{array}$ & $0.02(0.02)$ & $0.01(0.02)$ & $0.02(0.02)$ & $0.02(0.03)$ \\
\hline $\begin{array}{l}\text { Mean daily } \\
\text { sediment } \\
\text { yield } \\
\left(\mathrm{t} \mathrm{ha}^{-1}\right)\end{array}$ & $3.13(3.10)$ & $2.21(3.22)$ & $2.07(1.52)$ & $1.55(1.69)$ \\
\hline \multicolumn{5}{|l|}{ Discharge } \\
\hline $\mathrm{R} 2$ & 0.78 & & 0.70 & \\
\hline NSE & 0.63 & & 0.58 & \\
\hline PBIAS & 29.2 & & 24.3 & \\
\hline \multicolumn{5}{|c|}{ Sediment yield } \\
\hline $\mathrm{R} 2$ & 0.65 & & 0.55 & \\
\hline NSE & 0.47 & & 0.31 & \\
\hline PBIAS & 25.4 & & 33.8 & \\
\hline
\end{tabular}

a

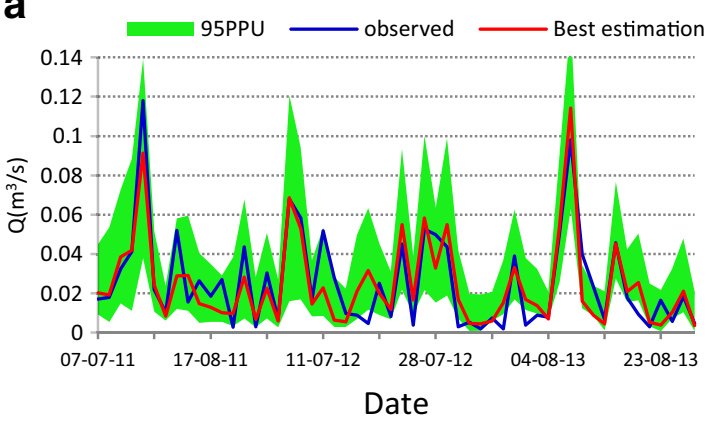

validation period in the UW (Fig. 8a) and a $R^{2}$ of 0.65 for calibration and 0.55 for validation period for the TW (Fig. 8b).

Daily sediment yield calibration and validation results showed NSE of 0.47 and 0.31 , respectively, for the TW and 0.54 and 0.33 for calibration and validation, respectively, for the UW (Table 4).

Results showed that SWAT model underestimated the generated sediment yield. The model predicted sediment yields of about 33.5 and $44.8 \mathrm{t} \mathrm{ha}^{-1}$ year $^{-1}$ for TW and UW, respective1y. The observed sediment yields were 39.9 and $64.6 \mathrm{t} \mathrm{ha}^{-1}$ year $^{-1}$ in TW and UW, respectively. The model underpredicted the annual sediment yield of the TW and the UW. This indicates that there is a potential impact of the SWC for sediment yield reduction in TW.

\section{Discussion}

The results show that the soil and water conservation structures constructed by the farmers reduce the surface runoff and soil losses in the highlands of Ethiopia. The results show that the untreated watershed had higher sediment and runoff losses than the treated watershed, given similar climatic and land use patterns. The intervention of SWC measures by the mobilization of the community has a significant soil loss reduction to protect their land from the rainfall-driven soil erosion. The effectiveness of SWC on runoff and sediment yield reduction has been reported in other studies in northern Ethiopia (Gebremichael et al. 2005; Haregewyn et al. 2005; Descheemaeker et al. 2006; Mitiku et al. 2006; Nyssen et al. 2007, 2009; Dagnew et al. 2015, 2017).

In this study, SWAT was used to assess the impacts of SWC on runoff and erosion processes, and the model has been found to be a useful tool for understanding the hydrologic processes and the sediment dynamic in the study area in both watersheds. The evaluation coefficients of the simulated daily runoff of the different objective functions for both the TW and UW indicated satisfactory model fit according to the assessment criteria (Moriasi et al. 2007). The NSE values found in

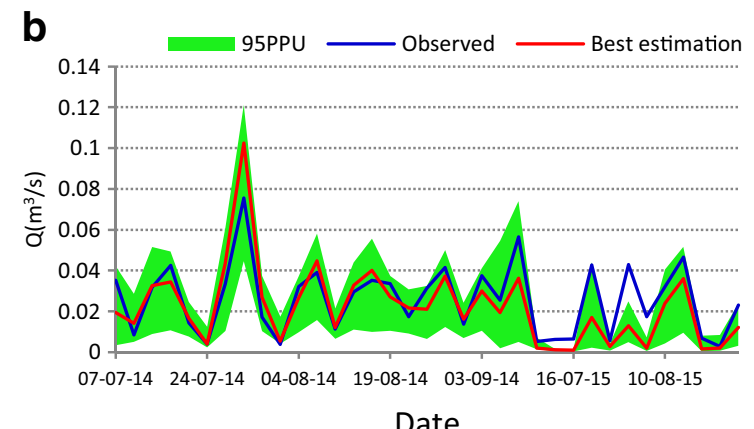

Date

Fig. 5 Observed and simulated daily runoff for calibration (a) and validation (b) periods at the outlet of the untreated watershed (UW) 

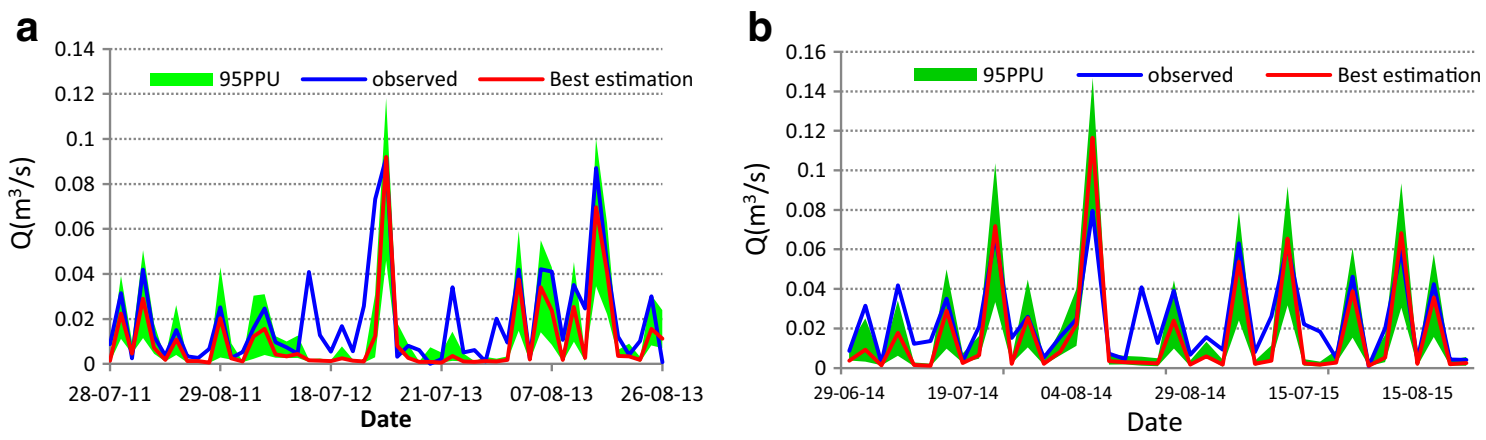

Fig. 6 Observed and simulated daily runoff for calibration (a) and validation (b) periods and at the outlet of the treated watershed (TW)
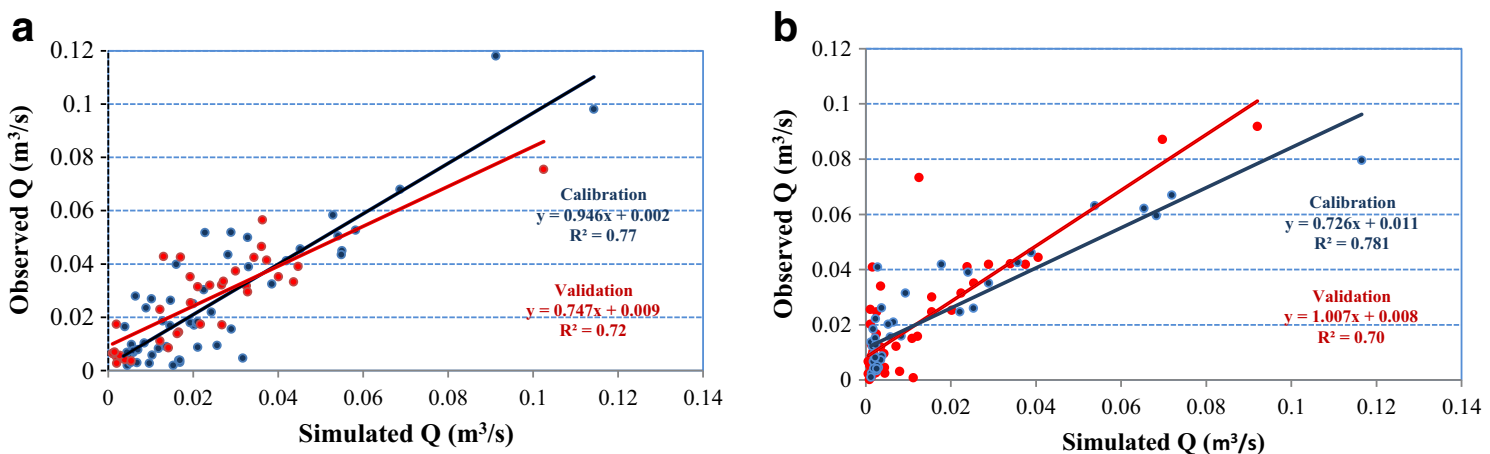

Fig. 7 Observed and simulated daily discharge $(Q)$ for calibration and validation periods at UW (a) and TW (b)

the UW and the TW agree with Khelifa et al. (2016) who studied the impact of SWC on runoff and sediment yield in Tunisia. These authors report NSE values for runoff simulations using SWAT of 0.64 and 0.68 for calibration and validation, respectively. In another study in the Gumara watershed by Zimale et al. (2016), the NSE values for daily flows obtained were 0.70 for calibration and 0.77 for validation period, which is comparable with the UW and TW NSE values in the Gumara-Maksegnit watersheds.

However, the model tends to underestimate sediment yield during calibration and validation periods for both watersheds. The NSE for sediment yield in both watersheds showed lower

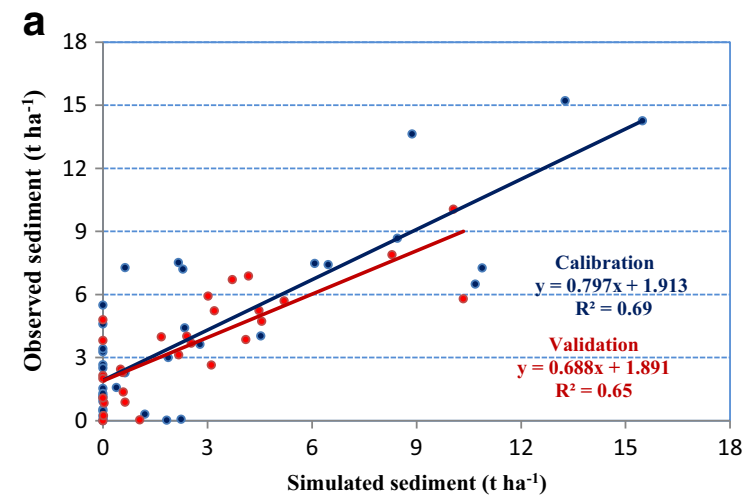

values in the calibration and validation periods. The underestimation of the sediment yield by the model is because there are parts of the watershed severely eroded which created gully erosion in both watersheds that led to higher soil losses beyond the estimated sediment load. This is substantiated by the photo taken in Fig. 9 which shows the development of deep gully in the upper parts of the watershed that contributes higher soil erosion losses that generate higher sediment load in the outlets.

The model result indicated that SWC structures may considerably reduce soil loss by $24.8-38.2 \%$ in the GumaraMaksegnit watershed. A plot-level experiment conducted on

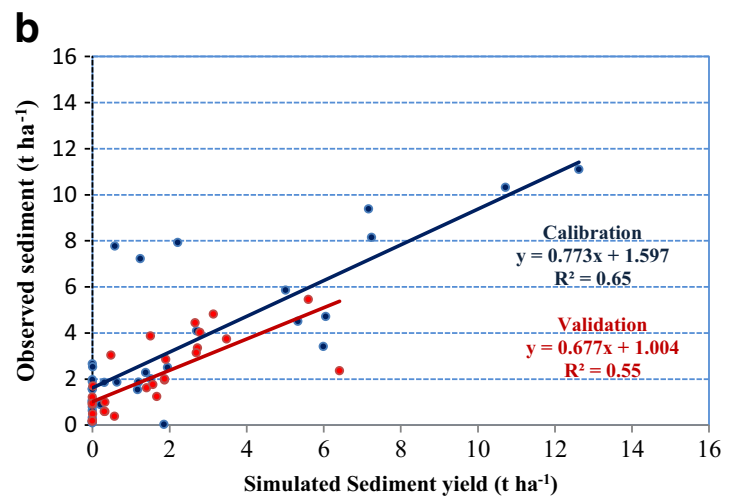

Fig. 8 Observed and simulated daily sediment for calibration and validation periods at UW (a) and TW (b) 
Fig. 9 Gully development in the upper part of the watershed (left) runoff with high sediment concentration at the outlets (right)
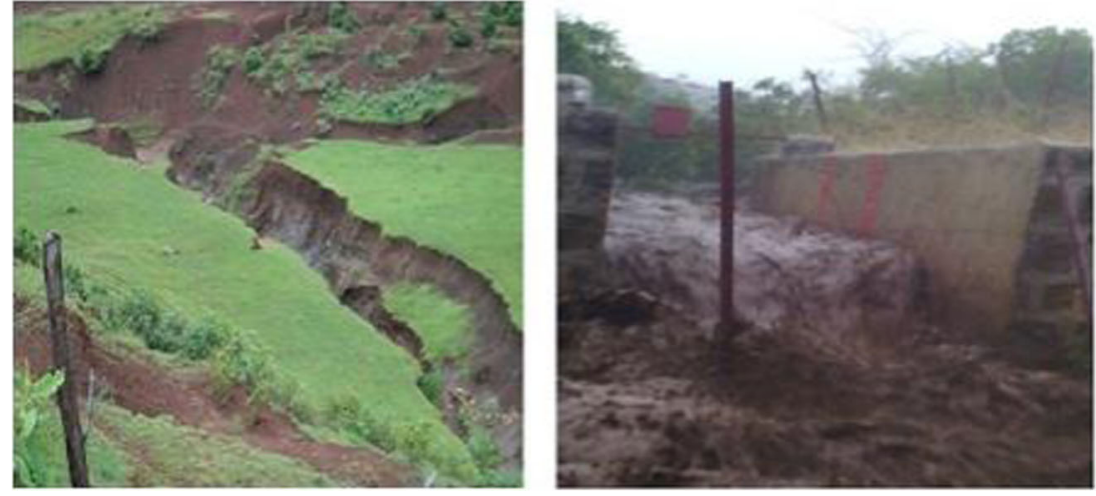

the effects of stone bunds showed that stone bunds can reduce soil erosion by 33-41\% (Rieder et al. 2014; Klik et al. 2016) in the TW which is close to the current finding of the soil loss reduction level due to SWC. Similarly, Strohmeier et al. (2015) reported that at plot scale, stone bunds reduced soil loss by $40 \%$ in the Gumara-Maksegnit watershed. In another study conducted in northern Tunisia on the effects of soil and water conservation structures on sediment load, Khelifa et al. (2016) reported $22 \%$ reduction in sediment yield at the watershed scale. Similar studies by Abouabdillah et al. (2014), Yesuf et al. (2015), Addis et al. (2016), and Licciardello et al. (2017) are in agreement with our findings. Betrie et al. (2011) also reported $41 \%$ reduction in sediment yield in the Blue Nile basin due to stone bunds. The soil loss reduction $(25-38 \%)$ in this study due to SWC structures at the watershed scale agreed with the findings of Abouabdillah et al. (2014) who estimated an overall soil loss reduction by $25 \%$.

The sediment yield estimated by SWAT model for the UW (44.8 $\mathrm{t} \mathrm{ha}^{-1}$ year $^{-1}$ ) and TW (33.5 $\mathrm{t} \mathrm{ha}^{-1}$ year $^{-1}$ ) was in agreement with other studies. Setegn et al. (2010) reported that sediment loads of 30-60 t ha ${ }^{-1}$ year $^{-1}$ were exported from the Lake Tana watersheds while Easton et al. (2010) predicted a maximum soil loss of $84 \mathrm{tha}^{-1}$ year ${ }^{-1}$ in the Gumara watershed. Similarly, Zimale et al. (2016) reported an average sediment yield of $49 \mathrm{t} \mathrm{ha}^{-1} \mathrm{y}^{-1}$ from the Gumara watershed. There are also a number of simulation studies on sediment load prediction at the gauging stations near Lake Tana (Easton et al. 2010; Setegn et al. 2010; Kaba et al. 2014; Zimale et al. 2016) which confirmed the results of the current study conducted in the Gumara-Maksegnit watershed.

\section{Conclusions}

Soil erosion is a serious problem in the Ethiopian highlands arising from agriculture intensification, deforestation, and land degradation. To find erosion hot-spot areas and to develop a soil conservation strategy, assessment of soil erosion is a useful tool. Empirical soil erosion modeling can provide a quantitative and consistent approach to estimate runoff and soil erosion under a wide range of conditions.

In this study, SWAT has been used to predict the impacts of SWC interventions on runoff and soil loss for two adjacent watersheds in the highlands of Ethiopia. SWAT-CUP has been used to perform calibration and validation of the observed and simulated runoff and soil losses. For UW and TW, separate SWAT and SWAT-CUP analyses were undertaken for estimating daily runoff and sediment yield.

The results of the simulation study showed good model performance for daily runoff prediction at each watershed with acceptable $R^{2}$, NSE, and PBIAS values. However, the model performance was poor in terms of predicting sediment loss with lower NSE values. Overall, the watershed modeling results indicated that soil and water conservation structures can reduce runoff and soil loss in the Gumara-Maksegnit watershed. Based on the calibrated SWAT model, the soil loss from the TW is found to be lower than that from the UW. The SWC structures reduced soil losses by $25-38 \%$ in the TW as compared to the UW. However, the soil erosion is still severe and above the world tolerable ranges $\left(2-11 \mathrm{t} \mathrm{ha}^{-1}\right.$ year $\left.^{-1}\right)$. Therefore, land management strategies and SWC structures should be improved to achieve more sustainable soil erosion protection for sustainable agriculture for food security in the area. Generally, this study supports the application of SWAT model to other watersheds in the Ethiopian highlands to predict the impact of SWC structures on runoff and soil erosion processes.

Acknowledgements Open access funding provided by University of Natural Resources and Life Sciences Vienna (BOKU). The authors are very grateful to the International Center for Agricultural Research in Dry Areas (ICARDA, Amman, Jordan), University of Natural Resources and Life Sciences (BOKU, Vienna, Austria), Amhara Agricultural Research institute (ARARI, Bahir dar, Ethiopia), Gondar Agricultural Research Center (GARC, Gondar, Ethiopia), Austrian Marshall Plan Foundation and University at Buffalo (The State University of New York, New York, USA) for the technical support.

Funding information The authors are very grateful to the International Center for Agricultural Research in Dry Areas (ICARDA, Amman, 
Jordan), University of Natural Resources and Life Sciences (BOKU, Vienna, Austria), Amhara Agricultural Research institute (ARARI, Bahir dar, Ethiopia), Gondar Agricultural Research Center (GARC, Gondar, Ethiopia), Austrian Marshall Plan Foundation and University at Buffalo (The State University of New York, New York, USA) for the financial support.

Open Access This article is distributed under the terms of the Creative Commons Attribution 4.0 International License (http:// creativecommons.org/licenses/by/4.0/), which permits unrestricted use, distribution, and reproduction in any medium, provided you give appropriate credit to the original author(s) and the source, provide a link to the Creative Commons license, and indicate if changes were made.

\section{References}

Abbaspour KC, Johnson A, Genuchten MT (2004) Estimating uncertain flow and transport parameters using a sequential uncertainty fitting procedure. Vadose Zone J 3(4):1340-1352. https://doi.org/10.2136/ vzj2004.1340

Abbaspour KC, Vejdani M, Haghighat S (2007) SWATCUP calibration and uncertainty programs for SWAT. In Proc. Intl. Congress on Modelling and Simulation (MODSIM'07), 2007; 1603-1609. L. Oxley and D. Kulasiri, eds. Melbourne, Australia: Modelling and Simulation Society of Australia and New Zealand

Abouabdillah A, White M, Arnold JG, De Girolamo AM, Oueslati O, Maataoui A, Lo Porto A (2014) Evaluation of soil and water conservation measures in a semi-arid river basin in Tunisia using SWAT. Soil Use Manag 30(4):539-549. https://doi.org/10.1111/sum.12146

Addis HK, Strohmeier S, Ziadat F, Melaku ND, Klik A (2016) Modeling streamflow and sediment using SWAT in the Ethiopian Highlands. Int J Agric Biol Eng 9:51-66

Adimassu Z, Mekonnen K, Yirga C, Kessler A (2014) Effect of soil bunds on runoff, soil and nutrient losses, and crop yield in the central highlands of Ethiopia. Land Degrad Dev 25(6):554-564. https:// doi.org/10.1002/ldr.2182

Arnold JG, Srinivasan R, Muttiah RS, Williams JR (1998) Large area hydrologic modeling and assessment part I: model development. J Am Water Resour As 34(1):73-89. https://doi.org/10.1111/j.17521688.1998.tb05961.x

Arnold J, Kiniry G, Srinivasan JR, Williams R, Haney JR, Neitsch SL (2011) SWAT input/output file documentation, version 2009. Grassland Soil and Water Research Laboratory, Temple

Belay KT, Van Rompaey A, Poesen J, Van Bruyssel S, Deckers J, Amare K (2014) Spatial analysis of land cover changes in eastern Tigray (Ethiopia) from 1965 to 2007: are there signs of a forest transition? Land Degrad Dev 25:130-142

Betrie GD, Mohamed YA, van Griensven A, Srinivasan R (2011) Sediment management modelling in the Blue Nile Basin using SWAT model. Hydrol Earth Syst Sci 15(3):807-818. https://doi. org/10.5194/hess-15-807-2011

Bonta JV (1997a) Determination of watershed curve number using derived distributions. J Irrig Drain Div American Soc Civ Eng 123(1): 28-36. https://doi.org/10.1061/(ASCE)0733-9437(1997)123:1(28)

Bonta JV (1997b) Determination of watershed curve number using derived distributions. J Irrig Drain Div Amer Soc Civ Eng 123(1):28 36. https://doi.org/10.1061/(ASCE)0733-9437(1997)123:1(28)

Dagnew DC, Guzman C, Zegeye A, Tibebu TY, Getaneh M, Abate S, Zemale FA, Ayana KE, Tilahun SA, Steenhuis TS (2015) Impact of conservation practices on runoff and soil loss in the sub-humid Ethiopian Highlands: the Debre Mawi watershed. J Hydrol Hydromech 63:210-219
Dagnew DC, Guzman C, Zegeye A, Akal AT, Moges MA, Tebebu AT, Mekuria W, Ayana EK, Tilahun SA, Steenhuis TS (2017) Sediment loss patterns in the sub-humid Ethiopian Highlands. Land Degrad Dev 28(6):1795-1805. https://doi.org/10.1002/ldr.2643

Descheemaeker K, Nyssen J, Rossi J, Poesen J, Haile M, Moeyersons J, Deckers J (2006) Sediment deposition and pedogenesis in exclosures in the Tigray Highlands, Ethiopia. Geoderma 132(3-4): 291-314. https://doi.org/10.1016/j.geoderma.2005.04.027

Di Luzio M, Srinivasan JR, Arnold JG (2002) Integration of watershed tools and SWAT model into BASINS. J Am Water Res Assoc 38(4): 1127-1141. https://doi.org/10.1111/j.1752-1688.2002.tb05551.x

Easton ZM, Fuka DR, White ED, Collick AS, Asharge B, McCartney M, Awulachew SB, Ahmed AA, Steenhuis TS (2010) A multi-basin SWAT model analysis of runoff and sedimentation in the Blue Nile, Ethiopia. Hydrol Earth Syst Sci Discuss 7(3):3837-3878. https://doi.org/10.5194/hessd-7-3837-2010

Erkossa T, Wudneh A, Desalegn B, Taye G (2015) Linking soil erosion to on-site financial cost: lessons from watersheds in the Blue Nile basin. Solid Earth 6(2):765-774. https://doi.org/10.5194/se-6-7652015

Ganasri BP, Ramesh H (2015) Assessment of soil erosion by RUSLE model using remote sensing and GIS - a case study of Nethravathi Basin. Geosci Front 7:953-961

Gassman PW, Reyes MR, Green CH, Arnold JG (2007) The soil and water assessment tool: historical development, applications, and future research directions. Trans ASABE 50(4):1211-1250. https:// doi.org/10.13031/2013.23637

Gebremichael D, Nyssen J, Poesen J, Deckers J, Haile M, Govers G, Moeyersons J (2005) Effectiveness of stone bunds in controlling soil erosion on cropland in the Tigray highlands, Northern Ethiopia. Soil Use Manag 21(3):287-297. https://doi.org/10.1079/ SUM2005321

Grum B, Woldearegay K, Hessel R, Baartman EM, Abdulkadir M, Yazewe E, Kessler A, Ritsema CJ, Geissen V (2017) Assessing the effect of water harvesting techniques on event-based hydrological responses and sediment yield at a catchment scale in northern Ethiopia using the Limburg Soil Erosion Model (LISEM). Catena 159:20-34. https://doi.org/10.1016/j.catena.2017.07.018

Gupta HV, Sorooshian S, Yapo PO (1999) Status of automatic calibration for hydrologic models: comparison with multilevel expert calibration. J Hydrol Eng 4(2):135-143. https://doi.org/10.1061/(ASCE) 1084-0699(1999)4:2(135)

Gupta HV, Beven KJ, Wagener T (2006) Model calibration and uncertainty estimation. In: Encyclopedia of hydrological sciences, pp 11131

Guzman C, Tilahun SA, Dagnew DC, Zegeye A, Tebebu TY, Yitaferu B, Steenhuis TS (2017) Modeling sediment concentration and discharge variations in a small Ethiopian watershed with contributions from an unpaved road. J Hydrol Hydromech 65(1):1-17. https://doi. org/10.1515/johh-2016-0051

Haregeweyn N, Poesen J, Nyssen J, Verstraeten G, de Vente J, Govers G, Deckers S, Moeyersons J (2005) Specific sediment yield in TigrayNorthern Ethiopia: assessment and semi-quantitative modelling. Geomorphology 69(1-4):315-331. https://doi.org/10.1016/j. geomorph.2005.02.001

Kaba E, Philpot W, Steenhuis T (2014) Evaluating suitability of MODISTerra images for reproducing historic sediment concentrations in water bodies: Lake Tana, Ethiopia. Int J Appl Earth Observ GeoInf 26:286-297. https://doi.org/10.1016/j.jag.2013.08.001

Kaltenleithner M, Strohmeier S, Melaku ND, Ziadat F, Klik A (2014) Investigation of the impact of stone bunds on soil water content - A case study in the northern Ethiopian Highland. Geophys Res Abstr Vol. 16, EGU2014-3915, 2014. EGU General Assembly 2014, Austria, Vienna 
Kebede W (2014) Effect of soil and water conservation measures and challenges for its adoption: Ethiopia in focus. J Environ Sci Technol 7:185-199

Keesstra S, Pereira P, Novara A, Brevik EC, Azorin-Molina C, ParrasAlcántara L, Jordán A, Cerdà A (2016) Effects of soil management techniques on soil water erosion in apricot orchards. Sci Total Environ 551-552:357-366

Khelifa WB, Hermassi T, Strohmeier S, Zucca C, Ziadat F, Boufaroua M, Habaieb H (2016) Parameterization of the effect of bench terraces on runoff and sediment yield by SWAT modeling in a small semi-arid watershed in Northern Tunisia. Land Degrad Dev 28:1568-1578

Klik A, Wakolbinger S, Obereder E, Strohmeier S, Melaku ND (2016) Impacts of stone bunds on soil loss and surface runoff: a case study from Gumara-Maksegnit Watershed, Northern Ethiopia. AgroEnviron 2016, Purdue University, West Lafayette, IN; 06/2016

Krause P, Boyle DP, Base F (2005) Comparison of different efficiency criteria for hydrological model assessment. Adv Geosci 5:89-97. https://doi.org/10.5194/adgeo-5-89-2005

Licciardello F, Toscano A, Cirelli GL, Consoli S, Barbagallo S (2017) Evaluation of sediment deposition in a Mediterranean reservoir: comparison of long term bathymetric measurements and SWAT estimations. Land Degrad Dev 28(2):566-578. https://doi.org/10. 1002/ldr.2557

Mitiku H, Herweg K, Stillhardt B (2006) Sustainable land managementa new approach to soil and water conservation in Ethiopia. Mekelle, Ethiopia: Land Resources Management and Environmental Protection Department, Mekelle University; Bern, Switzerland: Centre for Development and Environment (CDE), University of Bern, and Swiss National Centre of Competence in Research (NCCR) North-South. 269 pp

Moriasi DN, Arnold JG, Van Liew MW, Bingner RL, Harmel RD, Veith TL (2007) Model evaluation guidelines for systematic quantification of accuracy in watershed simulations. Trans ASABE 50(3):885900. https://doi.org/10.13031/2013.23153

Nash JE, Sutcliffe JV (1970) River flow forecasting through conceptual models: part I. A discussion of principles. J Hydrol 10(3):282-290. https://doi.org/10.1016/0022-1694(70)90255-6

Nigussie Z, Tsunekawa A, Haregeweyn N, Adgo E, Nohmi M, Tsubo M, Aklog D, Meshesha DT, Abele S (2017) Farmers' perception about soil erosion in Ethiopia. Land Degrad Dev 28(2):401-411. https:// doi.org/10.1002/ldr.2647

Nyssen J, Poesen J, Mitiku H, Moeyersons J, Deckers J (2000) Tillage erosion on slopes with soil conservation structures in the Ethiopian highlands. Soil Till Res 57(3):115-127. https://doi.org/10.1016/ S0167-1987(00)00138-0

Nyssen J, Poesen J, Gebremichael D, Vancampenhout K, D'aes M, Yihdego G, Govers G, Leirs H, Moeyersons J, Naudts J, Haregeweyn N, Mitiku H, Deckers J (2007) Interdisciplinary onsite evaluation of stone bunds to control soil erosion on cropland in Northern Ethiopia. Soil Till Res 94(1):151-163. https://doi.org/ 10.1016/j.still.2006.07.011

Nyssen J, Clymans W, Poesen J, Vandecasteele I, De Baets S, Haregeweyn N, Naudts J, Hadera A, Moeyersons J, Haile M (2009) How soil conservation affects the catchment sediment budget - a comprehensive study in the north Ethiopian highlands. Earth Surf Process Landf 34(9):1216-1233. https://doi.org/10.1002/esp. 1805

Obereder EM, Wakolbinger S, Guzmán G, Strohmeier S, Melaku ND, Gomez, Klik A (2016) Investigation of the Impact of Stone Bunds on Erosion and Deposition Processes combining Conventional and Tracer Methodology in the Gumara Maksegnit Watershed, Northern Highlands of Ethiopia. Geophys Res Abstr Vol. 18, EGU2016-2455-1, 2016. EGU General Assembly 2016, Austria, Vienna
Poitras V, Sushama L, Seglenieks F, Khaliq MN, Soulis E (2011) Projected changes to streamflow characteristics over Western Canada as simulated by the Canadian RCM. J Hydrometeorol 12(6):1395-1413. https://doi.org/10.1175/JHM-D-10-05002.1

Rieder J, Strohmeier S, Melaku ND, Ziadat F, Klik A (2014) Investigation of the impact of stone bunds on water erosion in northern Ethiopia. Geophysical Research Abstracts Vol. 16, EGU2014-3885, 2014. EGU General Assembly 2014, Austria, Vienna

Santhi C, Arnold JG, Williams JR, Dugas WA, Hauck L (2001) Validation of the SWAT model on a large river basin with point and nonpoint sources. J Am Water Res Assoc 37(5):1169-1188. https://doi.org/10.1111/j.1752-1688.2001.tb03630.x

Schuol J, Abbaspour KC (2007) Using monthly weather statistics to generate daily data in a SWAT model application to West Africa. Ecol Model 201(3-4):301-311. https://doi.org/10.1016/j.ecolmodel. 2006.09.028

Setegn SG, Srinivasan R, Dargahi B (2008) Hydrological Modeling in the Lake Tana Basin, Ethiopia using SWAT model. The Open Hydrology Journal. 2(2008): 49-62

Setegn SG, Melesse AM, Dargahi B, Srinivasan R (2009) Water Resources Variability as a Result of Changing Climate: A Case Study in the Lake Tana Basin, Blue Nile Ethiopia. Proceedings of the American Water Resources Association (AWRA) 2009 Spring Specialty Conference: Managing Water Resources Development in a Changing Climate, Anchorage, Alaska

Setegn SG, Srinivasan R, Melesse AM, Dargahi B (2010) SWAT model application and prediction uncertainty analysis in the Lake Tana Basin, Ethiopia. Hydrol Process 24:357-367

Setegn SG, Rayner D, Melesse AM, Dargahi B, Srinivasan R (2011) Impact of climate change on the hydroclimatology of Lake Tana Basin, Ethiopia. Water Resour Res, Vol. 47, W04511. https://doi. org/10.1029/2010WR009248

Strohmeier S, Rieder J, Kaltenleithner M, Melaku ND, Guzmán G, Ziadat F, Andreas Klik A (2015) Using magnetite tracer to evaluate a novel plot experimental design for the assessment of soil and water conservation impacts of stone bunds in Ethiopia. EGU General Assembly 2015; 04/2015

Sunday EO, Mohammed MB, John CN, Hermansah YW, Charles A, Toshiyuki W (2012) Soil degradation-induced decline in productivity of sub-Saharan African soils: the prospects of looking downwards the lowlands with the Sawah ecotechnology. Appl Environ Soil Sci 2012:1-10. https://doi.org/10.1155/2012/673926

Taguas EV, Guzmán E, Guzmán G, Vanwalleghem T, Gómez JA (2015) Characteristics and importance of rill and gully erosion: a case study in a small catchment of a marginal olive grove. Cuadernos de Investigación Geográfica 41-20. doi:https://doi.org/10.18172/cig. 2644

Teshome A, de Graaff J, Ritsema C, Kassie M (2016) Farmers' perceptions about the influence of land quality, land fragmentation and tenure systems on sustainable land management in the north western Ethiopian highlands. Land Degrad Dev 27(4):884-898. https://doi. org/10.1002/ldr.2298

Vancampenhout K, Nyssen J, Gebremichael D, Deckers J, Poesen J, Haile M, Moeyersons J (2006) Stone bunds for soil conservation in the northern Ethiopian highlands: impact on soil fertility and crop yield. Soil Till Res 90(1-2):1-15. https://doi.org/10.1016/j.still. 2005.08.004

Verstraeten G, Poesen J, Demare'e G, Salles C (2006) Long-term (105 years) variability in rain erosivity as derived from 10-min rainfall depth data for Ukkel (Brussels, Belgium): implications for assessing soil erosion rates. J Geophys Res 111(D22):D22109. https://doi.org/ 10.1029/2006JD007169

Yesuf HM, Assen M, Alamirew T, Assefa M, Melesse AM (2015) Modeling of sediment yield in Maybar gauged watershed using SWAT, northeast Ethiopia. Catena 120:191-205 
Zehetbauer I, Strohmeier S, Ziadat F, Klik A (2013) Runoff and sediment monitoring in an agricultural watershed in the Ethiopian Highlands. Geophysical Research Abstracts, 2013; vol. 15, p. 5640. EGU General Assembly 2013, Austria, Vienna
Zimale FA, Mogu MA, Alemu ML, Ayana EK, Demissie SS, Tilahun SA, Steenhuis TS (2016) Calculating the sediment budget of a tropical lake in the Blue Nile basin: Lake Tana. SOIL Discuss. https://doi. org/10.5194/soil-2015-84 